\title{
Principals' Gender-Related Variables and Discipline in Secondary Schools in Southwest, Nigeria
}

\author{
Akomolafe, Comfort Olufunke \\ Belo, Fawziyah Abimbola \\ Department of Educational Management, \\ Ekiti State University, Ado Ekiti, Nigeria
}

Doi: 10.19044/esj.2018.v14n13p190 URL:http://dx.doi.org/10.19044/esj.2018.v14n13p190

\begin{abstract}
The study examined the relationship between principals' genderrelated variables and discipline of teachers and students. The study was a descriptive research design of the survey type. The study population comprised 80, 291 teachers in Southwest Nigeria that comprised six states. A sample of 2,040 teachers was drawn from 102 Secondary Schools in 17 local Government Areas from three States in Southwest Nigeria using proportionate random and stratified sampling techniques. Data were collected with an instrument tagged "Gender-Related Variables and Discipline Questionnaire". The instrument was subjected to face and content validity by expert in Educational management and tests, to ensure the items measure what they are supposed to measure. The reliability of the instrument was established through test-retest method which yielded a coefficient of 0.78 . The hypotheses were tested with Pearson's Product Moment Correlation and Multiple Regression Analysis at 0.05 level of significance. It was revealed from the study that there was significant relationship between principals' gender-related variables and teachers' as well as students' discipline. It was also revealed from the study that courage of principals was the best predictor of teachers' discipline while principals' toughness was the best predictor of students' discipline. It was concluded on the basis of the findings of this study that gender-related variables are critical variables in the discipline of both teachers and students. It was therefore recommended that principals should regularly be reminded that their ability to discipline erring teachers and students is not a function of their sex but their personal attributes. It was equally recommended that principals' knowledge need to be updated on the need to maintain those variables such as courage, toughness and friendliness that contribute to their being effective in disciplining both teachers and students.
\end{abstract}


Keywords: Gender-related variables, Teachers' discipline, Students' discipline and Secondary school

\section{Introduction:}

Education serves as the backbone of development in any nation and improves the quality of life of a society through refinement of its potentials and as well enhances application of man's achievement towards improving his environment. This view was shared by Oboegbulem and Onwurah (2011) who asserted that education is the most important institution to produce a total man with the knowledge, attitude and skills required not only for the present world but also for the future generation.

Secondary education does not only occupy an important place in the Nigerian education system, it serves as a link between the primary and tertiary levels; and because of its central position, its programmes have functional roles such as giving students access to higher education as well as preparing them for work. Enose (2010) summed it up that educational organisations such as the secondary school system exist in a symbiotic relationship with their environment, utilising both human and material resources for the production of educated socialised graduates. In fulfilling this role, a lot is expected to be done by the school head in the judicious coordination of human and material resources available to his/her school.

Gender is one of the fundamental organizing principles of the society and its understanding goes a long way in increasing the understanding of men and women. It refers to the socio-cultural definition of man and woman. That is, the way in which they are differentiated and assigned with socially acceptable roles. Haussmann, Tyson and Zahidi (2008) submitted that gender is a matter of culture and refers to the social classification of men and women into masculine and feminine. They further argued that male-ness and female-ness are not biologically given, but rather, the result of a long historical process and that in each historical epoch, male-ness and female-ness are differently defined.

Gender-related variables which are the expected attributes of masculinity and femininity are powerful factors that are not only important in our daily lives but also in the organisation where people work. Human is either male or female, provided with either masculine or feminine qualities (Belo, 2016). It is believed that some traits have been attributed to masculine while some were also believed to be common among the feminine gender. Surprisingly, the so called associated gender-related variables differs among either sex. That is, associated attributes of a male could be more exhibited by the female and vice versa,

The importance of gender-related variables which include assertiveness, thoroughness, friendliness, toughness and courage cannot be 
over emphasized if the goals for which the school stands are to be achieved. This is because of the general belief that for a manager to achieve success in teachers' and students' discipline, he/she must be able to make his/her stand(s) clear, painstakingly do things without confusing his/her followers, be bold to face all challenges as well as be friendly without compromising indiscipline with his/her subordinates so that organizational goals could be achieved.

In addition, it is not an understatement that gender-related variables which goes beyond maleness and femaleness has become a necessary ingredient in disciplining both teachers and students if school goals are to be achieved. This corroborates Myer (2002) who submitted that the attributes of principals show the strength of character and dynamism needed to achieve some administrative goals. This implies that the gender-related variables exhibited by the principal play a vital role in accomplishing school objectives, and school objectives could best be achieved where there are disciplined teachers and students.

Discipline in schools refers to the ability of students, teachers and other workers in the environment to adhere to the schools' stated rules, standards or policies. Ikoya (2006) posited that disciplinary problems are attitudes or behaviour that ran contrary to laid down rules and regulations of the school. He concluded that most times, disciplinary problems make the objective of setting secondary education a mirage. Quality education is believed to be the right of every citizen and not a privilege that could be granted or withheld by those in charge. To achieve qualitative education, it is imperative that principals should strive hard in ensuring teachers' and students' discipline so that the goals for which the school stands could be attained.

Discipline is a trait of being well behaved, manifesting self-control and compliance with rules of conduct. Principals are expected to be disciplined before they can successfully instilled discipline in their teachers and students. It is worthy of note that principals should always avoid crisis in schools, but should however use appropriate management technique(s) to solve any disciplinary problem that arise. Bear (2010) contended that school principals should help teachers and students overcome disciplinary problems by employing management techniques that will help achieve the objectives of secondary education. He thus suggested the development of social problemsolving and decision-making skills among students, creation of environment that is conducive to teaching and learning, establishment and maintenance of close communication, strategic use of praise and rewards to maximize effectiveness in improving behaviour while minimising the risk of diminishing intrinsic motivation as some of the techniques for resolving discipline problems among teachers.

Disruptions and misbehaviours in schools were observed to be common universal phenomena which present obstacles to teaching and 
learning (Omotayo, 2008; Brue, 2009; Marias and Meier, 2010). Mpiso (2009) summed it up that good discipline is considered to be one of the major attributes of effective schools and many failing schools have been blamed for lack of discipline. Sharing these views, it could therefore be argued that principals should endeavour to exhibit masculine gender-related variables irrespective of their sex in order to ensure disciplined teachers and students which could in turn facilitate accomplishment of school goals.

Some principals seem to engage in illicit affairs with their teachers and some even lower their moral standard by engaging their students in immoral act, some engage in drinking beer/palm wine with their teachers as well as the students and even extorting money from their teachers and students thereby reducing the expected respect they deserve from the teachers and students. These give room for indiscipline which could in turn lead to nonaccomplishment of school objectives. Be it as it may, the proverb "as is the principal, so is the school" will not fail to apply for whatever the policies, strategies and of course effectiveness in terms of discipline ability of school administrators. This implies that gender-related variables of principals would either enhance or hinder their ability to instil discipline in their teachers and students.

\section{Statement of the Problem:}

There have been incessant complaints by parents, government and the society at large concerning secondary school teachers' and students' indiscipline. These seem to increase the level of cultism, indecent acquisition of results, delinquent behaviour, and lack of commitment among others. Reasons such as principals' managerial skills, leadership styles, communication behaviour among others have been attributed to this, but this work investigated teachers' and students' discipline vis-à-vis principals' gender-related variables. The problem of this study is therefore the seemingly non-clarity of the impact of gender-related variables on secondary school teachers' and students' discipline and which of the either gender can better enhance teachers' and students' discipline so that school goals could be achieved.

\section{Research Hypotheses:}

1. There is no significant relationship between principals' gender-related variables and teachers' discipline.

2. There is no significant relationship between principals' gender-related variables and students' discipline.

3. Gender-related variables of principals will not significantly contribute to teachers' discipline.

4. Gender-related variables of principals will not significantly contribute to students' discipline. 


\section{Methodology:}

The study is a descriptive research design of the survey type. The population of the study comprised 80,291 teachers in Southwest Nigeria. The sample for the study comprised 2,040 teachers that were selected from 17 Local Government Areas in Southwest Nigeria. In doing this, three states were randomly selected, and this was followed by selecting 17 Local Government Areas using proportionate stratified random sampling technique. This was followed by random selection of six schools per Local Government Area making a total of 102 schools. 2,040 teachers were thereafter selected using stratified random sampling technique at the rate of 20 teachers per school.

The instrument used for the study was a questionnaire titled "Genderrelated Variables and Discipline Questionnaire'. The instrument was validated by experts in Educational Management and Tests and Measurement in the Faculty of Education, Ekiti State University. The reliability of the instrument was established through test-retest method which yielded a coefficient of 0.78 . The data collected were analysed using Pearson's product moment correlation and multiple regression analysis. The hypotheses were tested at 0.05 level of significance.

\section{Data Analysis and Results:}

Hypothesis 1: There is no significant relationship between principals' gender-related variables and teachers' discipline.

Table 1: Relationship between principals' gender-related variables and teachers' discipline

\begin{tabular}{|l|l|l|l|l|l|}
\hline Variables & $N$ & Mean & $S D$ & r-cal & r-tab \\
\hline Gender-related variables & 2040 & 77.15 & 10.116 & & \\
\cline { 1 - 4 } Teachers' discipline & 2040 & 12.48 & 2.420 & $0.407^{*}$ & 0.195 \\
\hline
\end{tabular}

*significant at $\mathrm{P}<0.05$

Table 1 reveals that $r$-calculated $(0.407)$ is greater than r-table $(0.195)$ at 0.05 level of significance. The null hypothesis was therefore rejected. This implies that there was significant relationship between gender-related variables of principals and teachers' discipline.

Hypothesis 2: There is no significant relationship between principals' genderrelated variables and students' discipline.

Table 2: Relationship between principals' gender-related variables and students' discipline

\begin{tabular}{|l|l|l|l|l|l|}
\hline Variables & $N$ & Mean & $S D$ & r-cal & r-tab \\
\hline Gender-related variables & 2040 & 77.15 & 10.116 & & \\
\cline { 1 - 4 } Students' discipline & 2040 & 12.33 & 2.439 & $0.389^{*}$ & 0.195 \\
\hline
\end{tabular}

*significant at $\mathrm{P}<0.05$

Table 2 reveals that $r$-calculated $(0.389)$ is greater than r-table $(0.195)$ at 0.05 level of significance. Hence, the null hypothesis was rejected. This 
implies that there was significant relationship between principals' genderrelated variables and students' discipline.

Hypothesis 3: Gender-related variables of principals will not significantly contribute to teachers' discipline.

Table 3: Multiple Regression Analysis showing contribution to teachers' discipline by gender-related variables of principals

\begin{tabular}{|c|c|c|c|c|c|c|c|c|}
\hline Variables & B & $\begin{array}{l}\text { Std. } \\
\text { error }\end{array}$ & Beta & $\mathbf{T}$ & Sig & $\mathbf{R}$ & $\mathbf{R}^{2}$ & $\mathbf{F}$ \\
\hline Constant & 24.464 & & & & & & \multirow{6}{*}{$\begin{array}{l}n \\
\\
0\end{array}$} & \multirow{6}{*}{ 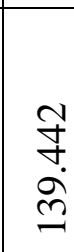 } \\
\hline Assertiveness & 0.006 & 0.028 & 0.007 & 0.230 & 0.818 & & & \\
\hline Friendliness & 0.137 & 0.024 & 0.158 & 5.730 & 0.000 & & & \\
\hline Thoroughness & 0.065 & 0.013 & 0.100 & 5.183 & 0.000 & & & \\
\hline Toughness & 0.125 & 0.024 & 0.266 & 5.119 & 0.000 & & & \\
\hline Courage & 0.224 & 0.025 & 0.266 & 9.023 & 0.000 & & & \\
\hline
\end{tabular}

Table 3 shows that gender-related variables of principals jointly and significantly contributed to teachers' discipline $(\mathrm{F}=139.442, \mathrm{P}<0.05)$. The null hypothesis was therefore rejected. The table reveals that the single best predictor of teachers' discipline is courage of principals, with a beta weight of $0.266(27 \%)$ and the least predictor is assertiveness with a beta weight of 0.007 $(0.7 \%)$.

Hypothesis 4: Gender-related variables of principals will not significantly contribute to students' discipline.

Table 4: Multiple Regression Analysis showing contribution to students' discipline by gender-related variables of principals

\begin{tabular}{|c|c|c|c|c|c|c|c|c|}
\hline Variables & B & $\begin{array}{l}\text { Std. } \\
\text { error }\end{array}$ & Beta & $\mathbf{T}$ & Sig & $\mathbf{R}$ & $\mathbf{R}^{2}$ & $\mathbf{F}$ \\
\hline Constant & 24.464 & & & & & \multirow{6}{*}{ 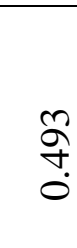 } & \multirow{6}{*}{ 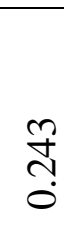 } & \multirow{6}{*}{$\begin{array}{l}N \\
\text { nn } \\
0 \\
n\end{array}$} \\
\hline Assertiveness & 0.056 & 0.028 & 0.056 & 1.952 & 0.051 & & & \\
\hline Friendliness & 0.141 & 0.024 & 0.162 & 5.808 & 0.000 & & & \\
\hline Thoroughness & 0.080 & 0.013 & 0.122 & 6.247 & 0.000 & & & \\
\hline Toughness & 0.225 & 0.025 & 0.265 & 9.039 & 0.000 & & & \\
\hline Courage & 0.075 & 0.025 & 0.088 & 2.961 & 0.003 & & & \\
\hline
\end{tabular}

Table 4 reveals that gender-related variables of principals, jointly and significantly contributed to students' discipline $(\mathrm{F}=130.572, \mathrm{P}<0.05)$. The null hypothesis was therefore rejected. The table also shows that the single best predictor of student discipline is toughness of principals, with a beta weight of $0.265(27 \%)$ and the least predictor is assertiveness with a beta weight of $0.056(6 \%)$.

\section{Discussion:}

The study revealed that there was a significant relationship between principal'gender-related variables and discipline of teachers and students in secondary schools in southwest Nigeria. This implies that principals who 
effectively utilised their attributes (assertiveness, thoroughness, friendliness, toughness and courage) are likely to succeed in teachers' and students' discipline. For instance, being friendly with members of staff does not imply that such principal should fail to sanction erring teachers and students. Probable reason why gender-related variables were significant to teachers' and students' discipline might be due to the assumption of the likelihood that the effective utilisation of gender-related variables could enhance discipline of both teachers and students which could in turn enhance attainment of school goals. The finding corroborates that of Uthman (2012) who found out that a positive connection exists between teachers and, students' discipline, and some of the identified gender-related variables in this study.

The study also revealed that courage of principals was the highest contributory factor to teachers' discipline. Implication of this is that there is likelihood of having disciplined teachers by principals who deal with all situations especially difficult conditions without being sentimental and are ready at all times to face challenges that might arise in the school rather than avoiding or neglecting it. Reason for this might be due to the fact that it is expected that a leader must be bold and fearless, not being wicked in his/her administration but rather be firm on decisions that would move the school forward. The study negates that of Hume (2012) who found out that tough principals are always bossy and that bossy principals are unsuccessful and unpopular in their administration.

The study equally revealed that toughness of the principal is the best predictor of students' discipline. Implication of this is that there is likelihood of having disciplined students by principals who embark on some elements of harshness without being sentimental. Reason for this might not be unconnected with the belief that secondary school students are at the adolescent stage which is characterized by lots of problems, hence the need for some elements of toughness in order to subdue them so that school goals could be achieved.

\section{Conclusion:}

On the basis of the findings of this study, it was concluded that principals' gender-related variables are essential ingredients of teachers' and students' discipline. The study confirmed that principals who exhibit masculine genderrelated variables irrespective of their sex towed towards the path of ensuring disciplined teachers and students.

\section{Recommendations:}

The following recommendations were made based on the findings and conclusion of the study: 
1. Seminars, workshops and conferences should be regularly organized by the government in general and the Teaching Service Commission in particular for school principals in order to keep on reminding them that their ability to discipline erring teachers and students is not based on their sex but on their personal attributes.

2. Principals' knowledge need to be updated on the need to maintain those variables (courage, toughness and friendliness) that contribute to their being effective in teachers' and students' discipline.

\section{References:}

1. Bear, G.G. (2010). From School Discipline to Self-Discipline. New York: Guilford Press.

2. Belo, F.A (2016). Gender related variables and Time Management as Determinant of secondary school Principals' Managerial Effectiveness in Southwest, Nigeria. An Unpublished Ph.D Thesis of Ekiti State University, Ado-Ekiti.

3. Brue, E. (2009). Academic Outcomes in School Classes with Markedly

Discipline Pupils. Social Psychology of Education: An International Journal, 12 (2), 481.

4. Enose, M.W. (2010). Management of Student Discipline in Secondary Schools in Kenya: A Case Study of Bungoma Country. Educational Research, 3(2), 172-175.

5. Haussmann, R; Tyson, L.D. and Zahidi, S. (2008). The Global Gender Gap Report. Geneva: World Economic Forum

6. Hume, D. (2014). Influence of School Principals' Behaviour on Administrative Effectiveness in Shiraz Region. Unpublished Ph.D Thesis, Iran: Shiraz University.

7. Ikoya, P.O. (2006). Gender Differences and Application of preventive Practices among Principals of Secondary School in Nigeria. DELSU Journal of Education, Research and Development, 5(6), 70-72.

8. Marias, P. and Meier, C. (2010). Disruptive Behaviour in the Foundation Phase of Schooling. South Africa Journal of Education, 30(3), 53-56.

9. Mpiso, S.P. (2009). The Perspective of Punishment and Principals' Performance: A Case Study of Secondary Schools in Mubenoe District. Unpublished M.Ed Thesis, Makerere, University. Myer, R. (2002). What's Needed: A Mixed Bag of Personalities. Retrieved April 25, 2004 from http://wwwboard member.com/network/index. p17 section 97. 
10. Myer, R. (2002). What's Needed: A Mixed Bag of Personalities. Retrieved April 25, 2004 from http://wwwboard member.com/ network/index. p17 section 97.

11. Myer, R. (2002). What's Needed: A Mixed Bag of Personalities. Retrieved April 25, 2004 from http://wwwboard member.com/network/index. p17 section 97.

12. Oboegbulem, A.I. and Onwurah, C. (2011). Organization and Management of Education: A Nigerian Perspective. Nsukka: Great AP Press Publishers Ltd.

13. Omotayo, H.K. (2008). Identification of Discipline Violations and its Role in Planning Corrective and Preventive Discipline by Secondary School Principals in South Nigeria. An Unpublished M.Ed Thesis, University of Calabar.

14. Uthman, I.O. (2012). How Principals deal with Students Discipline Problems in Nigeria. Secondary School. Unpublished M.Ed Thesis Ahmadu Bello University Zaria. 